\title{
KEMAMPUAN PENGENALAN GEOMETRI MELALUI KEGIATAN BERMAIN BALOK ANAK USIA 5-6 TAHUN
}

\author{
Lathipah Hasanah, Shinta Agung \\ Sekolah Tinggi Agama Islam Bani Saleh Jakarta \\ corresponding e-mail: latifahasanah@yahoo.com
}

\begin{abstract}
The purpose of this research is to improve the ability of introduction of geometry in the 5 to 6 year old children through blocks playing activities. The subject of this research is children in grade $B, R A A l-$ Watoniyah 16 Rawa Terate Cakung, East Jakarta. The method uses classroom action research. This research uses qualitative and quantitative approach according to Kemmis model which consists of four stages: planning, action, observation and reflection. The average score obtained in pre intervention is $35.90 \%$. Based on these results, interventions must be taken through blocks playing activities. After doing intervention in cycle $I$, the results obtain an average score of $61.52 \%$. Then intervention in cycle II obtains an average score of $80.97 \%$. Based on the results of research that has been implemented, blocks playing activities can improve the ability children to introduction geometry effectively. Furthermore, this activity also can improve the moral, cognitive, social emotional, language and motor development.
\end{abstract}

Keywords : Geometry Introduction, Block Activities, Children Aged 5-6 Years

\begin{abstract}
Abstrak
Penelitian ini bertujuan untuk meningkatkan kemampuan mengenal geometri pada anak usia 5-6 tahun melalui kegiatan bermain balok. Subjek penelitian ini adalah anak-anak kelompok B di RA Al-Wathoniyah 16 Rawa Terate Cakung, Jakarta Timur. Metode penelitian yang dilakukan oleh peneliti adalah metode penelitian tindakan kelas. Pendekatan yang digunakan adalah pendekatan kualitatif dan kuantitatif menurut model Kemmis yang terdiri dari empat komponen, yaitu: perencanaan, tindakan, observasi dan refleksi. Nilai rata-rata yang didapat pada praintervensi adalah $35.90 \%$. Berdasarkan hasil ini maka harus dilakukan tindakan intervensi melalui kegiatan bermain balok. Setelah melakukan intervensi tindakan siklus I maka diperoleh hasil nilai rata-rata sebesar $61.52 \%$. Kemudian dilakukan intervensi tindakan siklus II dan diperoleh nilai rata-rata $80.97 \%$. Berdasarkan hasil penelitian yang telah dilaksanakan, kegiatan bermain balok sangat efektif dapat meningkatkan kemampuan mengenal geometri pada anak. Selain itu, kegiatan ini juga dapat meningkatkan aspek moral, kognitif, social emosional, bahasa dan motorik.
\end{abstract}

Kata Kunci: Pengenalan Geometri, Bermain Balok, Anak Usia 5-6 Tahun 


\section{Pendahuluan}

Usia 5-6 tahun merupakan suatu masa dimana seorang anak ingin mencoba berbagai hal. Pemberian stimulasi sangat dibutuhkan oleh anak-anak, karena masa ini merupakan suatu masa dimana anak mampu menerima berbagai hal yang diberikan oleh orang dewasa yang ada di sekelilingnya. Pemberian stimulasi yang tepat akan memudahkan anak-anak untuk merekam berbagai hal di dalam otak dengan menggunakan berbagai inderanya. Banyak stimulasi yang dapat dikembangkan untuk anak. Salah satunya adalah pemberian stimulasi kognitif yang mengarah pada pengenalan geometri untuk anak usia dini.

Geometri merupakan bagian dari matematika yang sering kita temui dalam kehidupan sehari hari. Pemahaman bentuk geometri pada anak usia dini dimulai dari yang kongkret ke abstrak, dari segi intuisif ke analisis, dari eksplorasi ke pengusaaan dalam jangka waktu yang lama serta dari tahap yang paling sederhana hingga yang tinggi. Geometri merupakan dasar dalam matematika dan pembangunan. Selain dapat menumbuhkembangkan kemampuan berpikir logis, geometri juga efektif untuk membantu menyelesaikan permasalahan dalam banyak cabang matematika.

Pengenalan geometri sangat penting bagi anak usia dini. Walle menyatakan bahwa mempelajari geometri sangat penting, hal ini karena beberapa alasan antara lain: geometri banyak di temukan dalam kehidupan sehari-hari, melalui geometri dapat meningatkan anak dalam proses pemecahan masalah, geometri juga memiliki peran penting untuk mempelajari cabang matematika yang lain kemudian geometri juga dapat digunakan dalam kehidupan sehari-hari (Walle, 2001). Selain itu menurut Clement \& Battista \& Tan berpendapat bahwa geometri menyebabkan peningkatan berpikir geometri dalam pembelajaran untuk level berpikir matematika tingkat tinggi (Hwang dkk, 2009). Melihat hal tersebut dapat dilihat bahwa geometri sangat penting untuk dikenalkan pada anak usia dini.

Namun pada kenyataanya ada beberapa sekolah-sekolah yang belum maksimal dalam proses pengenalan geometri di sekolahnya. Seperti pada RA Al-Wathoniyah kemampuan pengenalan geometrinya masih rendah. Hal ini dapat dilihat pada tindakan praintervensi nilai rata-rata sebesar 25.85 atau 35.9\%. Hal ini disebabkan oleh banyak fantor salah satunya adalah metode pengenalan geometrinya yang kurang menarik.

Pengenalan geometri pada anak perlu diberikan melalui kegiatan yang menyenangkan, yaitu bermain. Pengenalan geometri melalui bermain akan membuat anak menjadi rileks, tidak merasa terbebani dan berdampak positif terhadap pembelajaran. Tidak hanya itu, dalam pemikiran anak pun akan terekam bahwa pengenalan geometri sangat menyenangkan dan tidak menakutkan. Dengan mengenalkan anak kepada geometri, diharapkan dapat membantu anak-anak untuk 
mempersiapkan diri dalam menghadapi perubahan zaman di dalam kehidupan yang terus berkembang, melalui berbagai latihan dasar anak diharapkan kelak mempunyai pola pemikiran yang logis, kritis dan rasional.

Strategi penyampaian yang tepat sangat dibutuhkan dalam pemahaman bentuk geometri dan dalam proses belajar mengajar agar dapat mengarahkan anak untuk memahami dan menguasai bentuk-bentuk dari geometri. Dalam prakteknya, belajar geometri pada anak usia dini diperlukan strategi pembelajaran yang berfungsi untuk memudahkan peserta didik untuk belajar. Setiap anak memiliki tingkat intelektual yang berbeda-beda sehingga perkembangan kemampuan berfikir anak dalam belajar pun berbeda pula. Perbedaan tersebut menyebabkan perbedaan penguasaan dan pemahaman konsep dan tahapan belajar yang dialaminya sebagai akibat dari berbagai faktor yang mempengaruhinya.

Salah satu strategi yang dapat diberikan guru dalam mengenalkan geometri kepada anak adalah melalui kegiatan bermain balok. Kegiatan bermain balok dapat menyalurkan dorongan-dorongan dalam diri anak untuk berimajinasi dan mengembangkan minat yang diinginkannya. Bermain balok sebagai alternatif kegiatan yang menyenangkan bagi anak-anak dalam kegiatan belajar geometri.

Di dalam kegiatan bermain balok terdapat langkah-langkah yang harus diperhatikan guru, yaitu mulai dari pembukaan, inti, dan penutup. Adapun kegiatan yang dilakukan guru pada kegiatan pembukaan adalah guru bercakap-cakap mengenai materi yang akan diajarkan anak-anak dalam kegiatan bermain balok berhubungan dengan matematika geometri. Selanjutnya guru dan anak bercakapcakap tentang kegiatan yang akan dilakukan. Kemudian guru akan memberikan peraturan yang akan disepakati bersama anak-anak dalam kegiatan bermain balok.

Taman kanak-kanak menjadi tempat bagi anak-anak untuk belajar memperluas pergaulan dalam kegiatan bermain yang melibatkan kemampuan anak dalam pengenalan geometri. Bagi anak-anak, bermain sebagai kegiatan yang menarik, menyenangkan dan menyalurkan energi anak. Melalui pengalaman yang menyenangkan, tentunya anak-anak akan termotivasi untuk belajar. Dengan demikian, diharapkan Taman Kanak-Kanak dapat dijadikan sarana yang tepat dalam membantu meningkatkan kemampuan geometri anak pada usia 5-6 tahun. Karena pada masa ini kognitif anak memasuki fase pra-operasional yang ditandai dengan berfungsinya kemampuan simbolis. Refleksi dari kemampuan ini dapat dilihat dari kemampuan anak untuk membayangkan benda-benda yang berada di sekitarnya secara mental. Hal ini berarti, anak akan dapat membayangkan bentuk benda walau tidak ada benda aslinya. Bermain balok sebagai alternatif yang menyenangkan bagi anak-anak dalam kegiatan belajar pengenalan geometri. 
Berdasarkan uraian di atas, penelitian ini sebagai salah satu upaya untuk meningkatkan kemampuan anak dalam pengenalan geometri melalui kegiatan bermain balok untuk anak kelompok B di taman kanak-kanak.

\section{Metode}

Metode yang digunakan adalah penelitian tindakan kelas (classroom action research), yaitu merupakan salah satu tipe dari penelitian tindakan (action research). Penelitian tindakan kelas pada prinsipnya dimaksudkan untuk mengembangkan keterampilan atau untuk memecahkan suatu permasalahan di kelas (Handini 2012: 20). Hal ini ditegaskan oleh McNiff bahwa dasar utama dari metode ini adalah untuk perbaikan dan peningkatan layanan profesional pendidik dalam menangani proses belajar mengajar dengan melakukan berbagai tindakan alternatif dalam memecahkan persoalan pembelajaran. Dalam hal ini peneliti atau guru melakukan sesuatu yang arah dan tujuan penelitiannya sudah jelas, yaitu demi kepentingan peserta didik dalam memperoleh hasil belajar yang memuaskan. Dalam penelitian tindakan terdapat dua aktivitas yang dilakukan secara simultan, yaitu aktivitas tindakan (action) dan aktivitas penelitian (research) (Arikunto 2006: 106). Kedua aktivitas tersebut dapat dilakukan orang yang sama atau orang yang berbeda yang bekerja sama secara kolaboratif.

Desain intervensi tindakan atau rancangan siklus penelitian ini menggunakan model Kemmis dan Taggart. Prosedur kerja dalam penelitian tindakan menurut Kemmis dan Taggart dalam Arikunto, meliputi tahap-tahap sebagai berikut: (a) perencanaan (planning), (b) tindakan (acting), (c) observasi (observing), (d) refleksi (reflecting), kemudian dilanjutkan dengan perencanaan ulang (replanning), tindakan, observasi, dan reflesi untuk siklus berikutnya, begitu seterusnya sehingga membentuk suatu spiral.

Indikator keberhasilan tindakan berupa besarnya persentase kenaikan minimal sebesar $71 \%$. Indikator keberhasilan ini sesuai dengan pendapat Mills yang menyatakan bahwa the end-ofsurvey revealed that 71\% of student agreed (Mills 2003: 101). Berdasarkan pendapat tersebut maka peneliti bersama dengan kolaborator menetapkan indikator keberhasilan penelitian tindakan kelas ini 71\%. Jika persentase yang diperoleh kurang dari $71 \%$ seperti yang telah disepakati bersama maka penelitian akan dilanjutkan pada siklus selanjutnya.

Penelitian ini mendeskripsikan bagaimana kegiatan bermain balok dapat meningkatkan kemampuan mengenal geometri anak usia 5-6 tahun. Sumber data dalam penelitian ini adalah anak-anak usia 5-6 Tahun yang merupakan sumber data primer, kepala sekolah yang dapat memberikan informasi mengenai kegiatan pembelajaran di sekolah, dan kolaborator yang terlibat dalam penelitian yaitu guru kelas. 


\section{Hasil dan Pembahasan}

Data penelitian ini dideskripsikan dalam bentuk penyajian data secara kuantitatif dan kualitatif. Data kuantitatif untuk melihat persentase kenaikan pada setiap siklusnya. Sedangkan data kualitatif untuk menganalisis data yang diperoleh melalui catatan lapangan, catatan wawancara, dan catatan dokumentasi di lapangan. Hasil peningkatan kemampuan pengenalan geometri melalui kegiatan bermain balok pada seluruh subjek penelitian dari hasil praintervensi, siklus I sampai dengan hasil intervensi siklus II disajikan dalam tabel berikut:

\section{Grafik 1}

Skor Hasil Praintervensi, Siklus I dan Siklus II

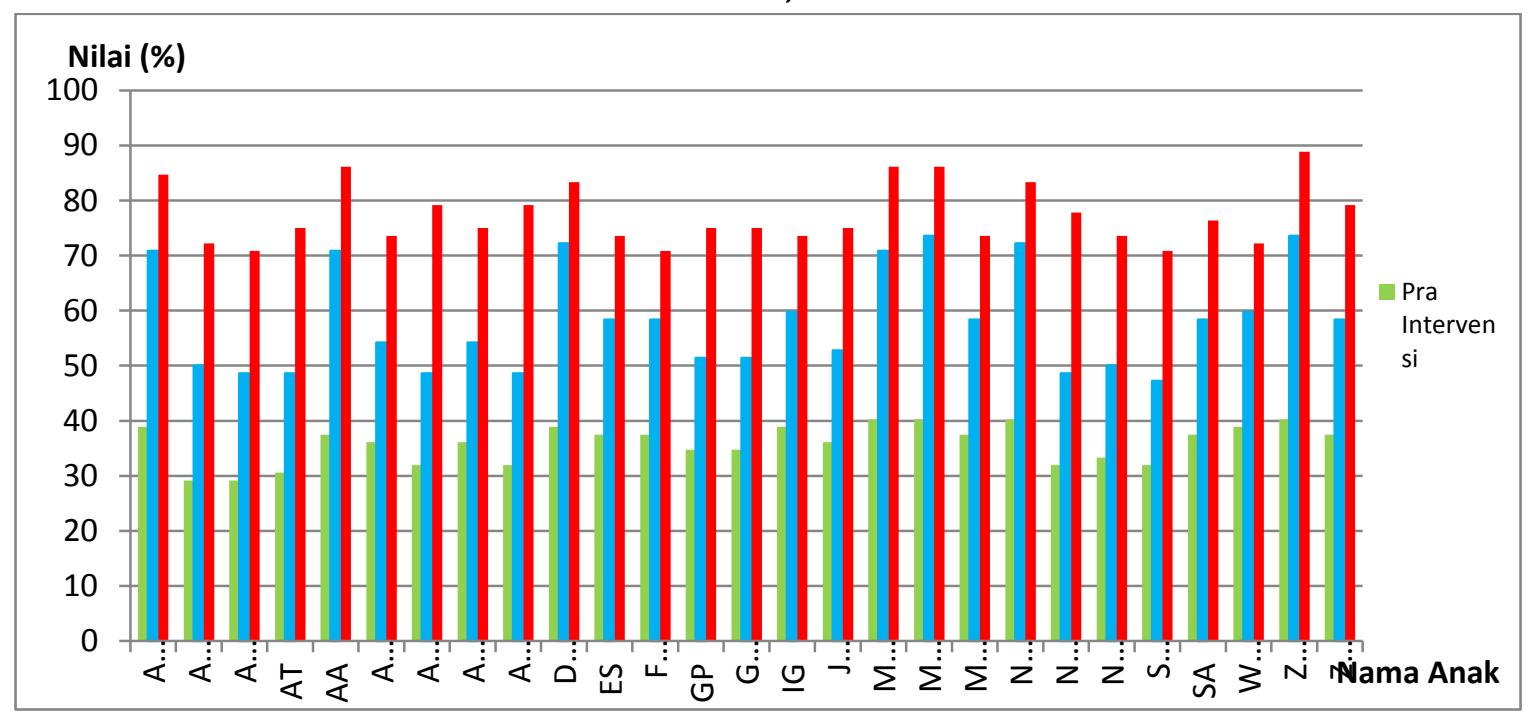

Tabel 4

Nilai Rata-Rata Hasil Praintervensi,Siklus I dan Siklus II

\begin{tabular}{lc}
\hline \multicolumn{1}{c}{ Keterangan } & Prosentase (\%) \\
\hline Praintervensi & 35.9 \\
\hline Siklus I & 62.19 \\
\hline Siklus II & 80.97 \\
\hline
\end{tabular}

Grafik 2

Nilai Rata-Rata Hasil Praintervensi,Siklus I dan Siklus II

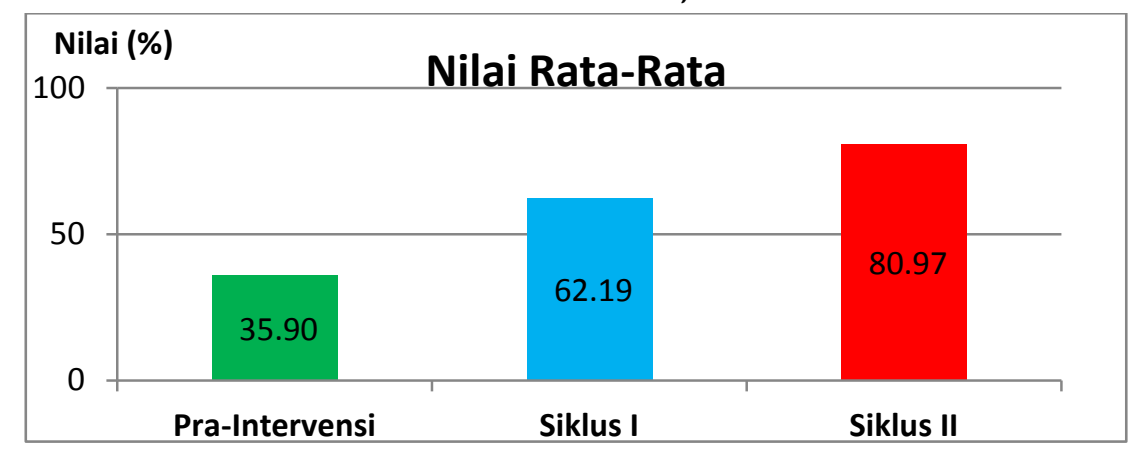

Dari tabel tersebut dapat disimpulkan bahwa nilai rata-rata pada setiap tindakan mengalami peningkatan yang signifikan. Pada tindakan praintervensi nilai 
rata-rata sebesar 25.85 atau $35.9 \%$ dan meningkat pada siklus I yaitu nilai rataratanya menjadi 44.77 atau $62.19 \%$ kemudian mengalami peningkatan lagi pada siklus II yaitu nilai rata-ratanya menjadi 58.30 atau $80.97 \%$.

Dari tindakan siklus II dinyatakan bahwa hipotesis tindakan telah tercapai sesuai dengan kriteria ketercapaian yang diharapkan atau berkembang sangat baik yaitu setara dengan persentase $\geq 71 \%$. Dengan demikian pembelajaran yang dilakukan pada siklus I dan siklus II telah berhasil. Peneliti dan kolaborator menyepakati bahwa tindakan dihentikan.

\section{Gambar 1}

Hasil Temuan Penelitian

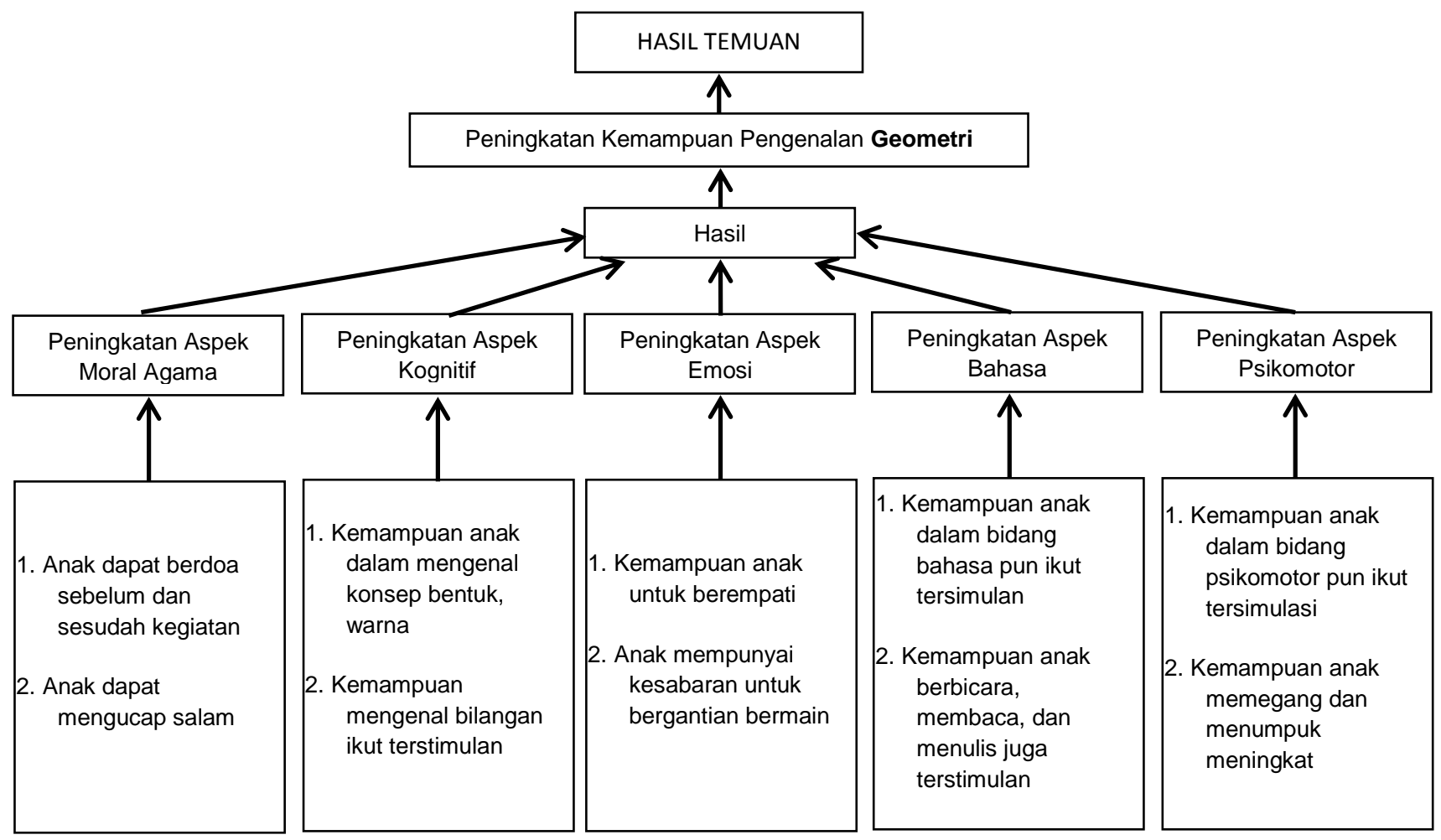

Hasil analisis data pada penelitian ini dikatakan berhasil jika hasil kemampuan pengenalan geometri pada anak sudah mencapai persentase $\geq 71 \%$. Berdasarkan analisis data terjadi kenaikan hasil rata-rata pada siklus I dimana pada saat praintervensi nilai rata-ratanya hanya sebesar 35.9\% kemudian meningkat menjadi $62.19 \%$. Nilai rata-rata peningkatannya sebesar $26.29 \%$ setelah diberikan tindakan pada siklus I. Kemudian pada suklus II mengalami peningkatan lagi yaitu nilai rataratanya menjadi $80.97 \%$ atau meningkat sebesar $18.78 \%$ dari siklus sebelumnya atau siklus I. Oleh karena itu, peneliti dan kolaborator merasa hasil yang didapat telah mencapai target yang diinginkan sehingga peneliti dan kolaborator memutuskan untuk menghentikan penelitian. 
Hasil data kuantitatif dan kualitatif membuktikan bahwa penerapan kegiatan bermain balok dapat meningkatkan kemampuan mengenal geometri pada anak. Hal tersebut terlihat bahwa anak sudah mampu untuk mengenal bentuk-bentuk geometri, mengelompokkan menurut bentuk, ukuran maupun warna dan mencocokkan benda-benda geometri dan membangun sesuatu dengan media balokbalok. Dengan demikian, hipotesis tindakan yang menyatakan bahwa kegiatan bermain balok dapat meningkatkan kemampuan pengenalan geometri anak usia 5-6 tahun diterima.

\section{Simpulan}

Berdasarkan hasil penelitian yang telah dilaksanakan oleh peneliti tentang peningkatkan kemampuan pengenalan geometri melalui kegiatan bermain balok anak usia 5-6 tahun di RA Al-Wathoniyah 16 Cakung Jakarta Timur, dapat disimpulkan bahwa kegiatan bermain balok dapat meningkatkan kemampuan anak dalam mengenal geometri.

Hal ini terlihat pada saat praintervensi, sebanyak 27 anak nilainya tidak mencapai kriteria yang telah ditetapkan yaitu sebesar $\geq 71 \%$. Nilai rata-ratanya sebesar 25.85 atau $35.90 \%$. Sedangkan pada siklus I, jumlah anak yang mencapai kriteria yang ditetapkan sebanyak 14 anak dimana nilai rata-ratanya sebesar 44.77 atau $62.19 \%$ sehingga perlu dilakukan tindakan selanjutnya atau tindakan siklus II. Kemudian pada saat siklus II, terjadi peningkatan dimana seluruh anak sebanyak 27 orang memperoleh nilai sesuai dengan kriteria yang telah ditetapkan. Nilai rataratanya sebesar 58.30 atau $80.97 \%$.

Secara kualitatif peningkatan kemampuan anak dalam mengenal geometri juga terlihat dari meningkatnya aspek moral agama, aspek kognitif, aspek emosi, aspek bahasa, dan aspek motorik. Aspek moral agama meningkat yaitu kemampuan berdoa dan mengucap salam. Aspek kognitif yaitu kemampuan anak mengenal konsep bentuk, warna meningkat. Aspek emosi yaitu meningkatnya empati dan kesabaran anak. Aspek bahasa yaitu meningkatnya kemampuan berbicara dan membaca. Dan kemudian dari aspek motorik yaitu kemampuan memegang dan menumpuk meningkat juga. Berdasarkan hasil tersebut maka tindakan dihentikan dan penelitian selesai karena telah mencapai target yang diharapkan dan sesuai dengan perencanaan yang telah ditetapkan.

Berdasarkan kesimpulan yang telah dipaparkan, ada beberapa saran dari peneliti, diantaranya: 1) Bagi lembaga PAUD, agar semakin mengembangkan strategi pembelajaran, menyediakan sarana dan prasarana yang memadai serta meningkatkan kualitas sumber daya tenaga pendidik; 2) Bagi kepala sekolah, meningkatkan profesionalisme guru serta keaktifan dalam kerjasama pada proses pembelajaran; 3) Bagi guru, meningkatkan penguasaan materi dan keterampilan dalam mengajar anak didiknya; 4) Bagi orang tua, memberikan dukungan serta 
stimulus yang tepat dalam mengembangkan kemampuan anak serta menyediakan fasilitas-fasilitas untuk belajar di rumah; 5) Bagi masyarakat, menyediakan sarana atau fasilitas serta memberikan kesempatan pada anak dalam rangka mengembangkan kemampuan pengenalan geometri; 6) Bagi peneliti selanjutnya, dapat melakukan penelitian mengenai peningkatan kemampuan pengenalan geometri pada aspek-aspek yang lain dengan meningkatkan kualitas, baik dari segi media maupun pelaksanaan sehingga dapat mencapai hasil yang lebih optimal.[]

\section{Daftar Rujukan}

Arikunto, Suharsimi. (2006). Penelitian Tindakan Kelas. Jakarta: Bumi Aksara.

Depdiknas. (2004). Bahan Pelatihan Lebih Jauh Tentang Sentra dan Saat Lingkaran; Main Pembangunan Jilid 4. Jakarta: Depdiknas.

Direktorat Pendidikan Anak Usia Dini. (2004). Main Pembangunan. Jakarta: Departemen Pendidikan Nasional.

Handini, Myrnawati Crie. (2012). Metodologi Penelitian untuk Pemula. Jakarta: FIP Press.

Isbell, Rebecca. (2001). The Complete Learning Center Book. Maryland: Gryphon House, Inc.

Mills, Geoffrey E. (2003). Action Research: A Guide For Teacher Research. New Jersey: Pearson Education.

Runtukahu, J Tombokan. (2000). Pengajaran Matematika Bagi Anak Berkesulitan Belajar. Jakarta: Departemen Pendidikan Nasional.

Tedjasaputra, Mayke S. (2001). Bermain dan Permainan. Jakarta: Grasindo.

Utami Munandar. (2000). Mengembangkan Bakat dan Kreatifitas Anak Sekolah. Jakarta: PT. Gramedia Widiasarana

Wibowo. (2013). Perilaku Dalam Organisasi. Jakarta: PT. Rajawali Gravindo Persada.

Walle, Van de J. A. (2001). Geometric Thinking and Geometric Concepts. In Elementary and Middle School Mathematics: Teaching Developmentally, 4th ed. Boston: Allyn and Bacon. 